\title{
Policy Learning dalam Formulasi Kebijakan Penanggulangan Kemiskinan Daerah: Insight dari Gunungkidul
}

\section{Fajar Sodiq Irawan}

\begin{abstract}
Studies on policy learning in the formulation of public policies have received less attention in the era of decentralization. This article aims to discuss policy learning in the formulation of local poverty reduction policies. By taking a case study in Gunungkidul Regency, this study shows that the learning carried out is conceptual learning which changes the perspective on local poverty reduction, from problem-based to assetbased. The form of policy learning that occurs is by selective imitation, which is taking certain elements to be included in the policy and not taking it in detail to avoids political risks. This policy learning model has implications for the implementation of policies that do not explicitly create new activities, but complement existing activity programs. The policy learning process at first glance appears as an administrative process, but in essence it is very political because it involves various actors with various interests.
\end{abstract}

\section{Keywords}

Policy learning; local government; decentralization; poverty reduction; Gunungkidul

\section{Pendahuluan}

Perubahan sistem politik dan pemerintahan di era desentralisasi membuat pemerintah daerah menjadi lebih leluasa untuk membuat kebijakan publik yang menyangkut kepentingan daerahnya. Pembuatan kebijakan publik ini menjadi menarik ketika para pembuat kebijakan di daerah ramai-ramai memamerkan inovasi dari daerahnya masing-masing. Pembuatan kebijakan tidak lagi monoton top down dan menunggu instruksi pusat. Para pembuat kebijakan di daerah memacu kreativitas untuk membuat kebijakan yang lebih efektif diterapkan, lebih terbuka dan inklusif, bahkan terang-terangan mengambil pelajaran dari praktekpraktek kebijakan yang berhasil di daerah lain. Pembelajaran yang digunakan oleh pemerintah sebagai dasar untuk membuat kebijakan inilah yang dinamakan dengan policy learning (Bennet dan Howlett 1992, 278). Artikel ini mendiskusikan policy learning dalam formulasi kebijakan penanggulangan kemiskinan daerah era

Fajar Sodiq Irawan adalah Kepala Seksi Pelatihan Keuangan dan Aset Desa (Widyaiswara Ahli Muda) Balai Pemerintahan Desa Yogyakarta, Kementerian Dalam Negeri Indonesia.

\section{Corresponding Author:}

Fajar Sodiq Irawan, Balai Pemerintahan Desa Yogyakarta, Yogyakarta, Indonesia.

Email: fajarbaru@gmail.com 
desentralisasi di Indonesia. Konteks lokus dan fokus yang diambil adalah kasus reformulasi kebijakan penanggulangan kemiskinan di Kabupaten Gunungkidul, Daerah Istimewa Yogyakarta. Dua pertanyaan penting yang dielaborasi adalah mengapa policy learning dilakukan dan bagaimana proses policy learning dijalankan. Pertanyaan mengapa akan mengupas lebih jauh motif yang dilakukan, serta hal-hal apa sajakah yang mendasari dilakukannya policy learning. Kemudian pertanyaan kedua tentang bagaimana, mengantarkan kita kepada proses policy learning yang dilakukan sepanjang proses formulasi kebijakan. Dari hal ini bisa diketahui aktor-aktor penting yang terlibat, apa saja yang dipelajari, dan sejauh mana pengaruh learning yang telah dilakukan mempengaruhi kebijakan. Dengan demikian, motif, aktor, proses, dan hasil policy learning akan tergambar lebih detail.

Kajian ini memberikan sumbangan yang berbeda dengan penelitian-penelitian sebelumnya, yang kebanyakan berhenti pada rekomendasi-rekomendasi kebijakan penanggulangan kemiskinan daerah. Penelitian ini lebih fokus menjawab pertanyaan tentang bagaimana rekomendasi-rekomendasi kebijakan yang ditujukan dipelajari oleh para pembuat kebijakan dan kemudian diformulasikan menjadi kebijakan daerah. Penelitian-penelitan sebelumnya kurang memberi perhatian pada aspek bagaimana para pembuat kebijakan belajar dari hasil kajian, penelitian, dan kebijakan lain untuk memformulasikan atau mereformulasi suatu kebijakan. Studi ini merupakan sambungan penting dalam menghubungkan antara rekomendasi kebijakan yang diusulkan oleh berbagai pihak dan kebijakan yang dibuat oleh pemerintah daerah. Cara-cara pemerintah daerah belajar untuk memformulasikan suatu kebijakan menjadi pintu masuk yang penting dalam mengadvokasi rekomendasi-rekomendasi dalam pembuatan kebijakan daerah.

Sistematika diskusi dalam artikel ini dimulai dengan refleksi konseptual mengenai policy learning dalam pembuatan kebijakan publik, serta deskripsi tentang konteks dan studi kasus yang dipilih dalam penelitian ini. Kemudian dilanjutkan dengan pemaparan sekilas tentang metode penelitian yang digunakan. Bagian berikutnya membahas temuan utama penelitian ini yang terdiri dari tiga bagian. Pertama, bagian ini menjelaskan kegagalan kebijakan penanggulangan kemiskinan daerah di Gunungkidul, berbasis kajian kritiis yang sudah ada. Kedua, bagian ini mendiskusikan proses reformulasi kebijakan penanggulangan kemiskinan daerah yang mengandung policy learning dalam proses penyusunannya. Ketiga, bagian ini menyajikan kebijakan hasil policy learning yang telah dilakukan. Diskusi kemudian diakhiri dengan kesimpulan yang merefleksikan jawaban atas rumusan masalah dalam studi ini.

\section{Literature Review}

\section{Proses Policy Learning dalam Pembuatan Kebijakan Publik}

Policy learning di sini dipahami sebagai sebuah proses di mana pengetahuan tentang kebijakan, pengaturan administratif, institusi, dan ide-ide dalam suatu sistem politik digunakan untuk pengembangan suatu sistem politik lain (Dolowitz dan Marsh 2000, 5). Karl Deutsch (1996) ketika membahas mengenai policy learning selalu membahas mengenai govermental learning capacity. Sementara itu, 
Hugh Heclo (1974) membahas bagaimana political learning membuat perubahan dalam kebijakan sosial dan inovasi kebijakan yang baru. Heclo juga mengenalkan social learning sebagai perubahan dalam perilaku yang merupakan hasil dari pengalaman. Sabatier (1988) dan Jenkins-Smith (1990) mengkarakterisasi "policy oriented learning" dalam bentuk yang sama dalam mengonseptualisasi learning dalam dan antar grup advokasi berbeda yang membahas sebuah kebijakan. Pengamatan dalam pengalaman kebijakan dapat secara langsung maupun tidak langsung. Rose (1991) menggunakan terminologi lesson drawing untuk mendapatkan pengalaman dari kebijakan secara tidak langsung. Anne Scheneider dan Helen Ingram (1998) menggunakan istilah "pinching of ideas" dari kebijakan lain atau pengalaman pemerintah lain (May 1992, 332-335).

Bennet dan Howlett $(1992,275-278)$ melakukan pemetaan mengenai konsepsi learning dan perannya dalam formulasi kebijakan publik. Secara umum teoritisasi policy learning merujuk pada 5 konsepsi. Di antaranya adalah political learning yang dikembangkan oleh Heclo, policy oriented learning yang dikembangkan oleh Sabatier, lesson drawing yang dikembangkan oleh Rose, social learning yang didiskusikan oleh Hall dan goverment learning yang diidentifikasi oleh Etheredge. Konsep-konsep ini sering digunakan oleh para analis untuk menjelaskan tendensi untuk keputusan kebijakan yang dibuat berdasarkan basis pengetahuan dari pengalaman terdahulu dan justifikasi berbasis pengetahuan untuk ekspektasi keberhasilan di masa depan. Pemerintah melakukan perubahan ketika mereka melakukan pembelajaran. Pembelajaran yang digunakan oleh pemerintah sebagai dasar untuk membuat kebijakan inilah yang dinamakan policy learning. Adanya perubahan kebijakan merupakan indikasi adanya policy learning (Hall 1993, 275).

Secara sekilas, policy learning ini mirip dengan evaluasi kebijakan. Keduanya sama-sama menilai hasil kebijakan yang telah dilakukan. Namun bedanya dalam evaluasi kebijakan, kegiatan yang dilakukan adalah sebatas penilaian implementasi kebijakan apakah menghasilkan output dan outcome yang dikehendaki, sedangkan dalam policy learning melihat secara keseluruhan proses tahapan kebijakan mulai dari agenda setting, formulasi kebijakan, implementasi kebijakan dan tahap monitoring dan evaluasi kebijakan dan kemudian mengambil pembelajaran untuk membuat kebijakan baru yang lebih efektif secara komperhensif. Sehingga policy learning memiliki cakupan yang lebih luas daripada evaluasi kebijakan. Posisi policy learning dalam proses kebijakan publik dapat digambarkan dalam bagan berikut: 


\section{Bagan 1. Pembelajaran dalam siklus kebijakan}

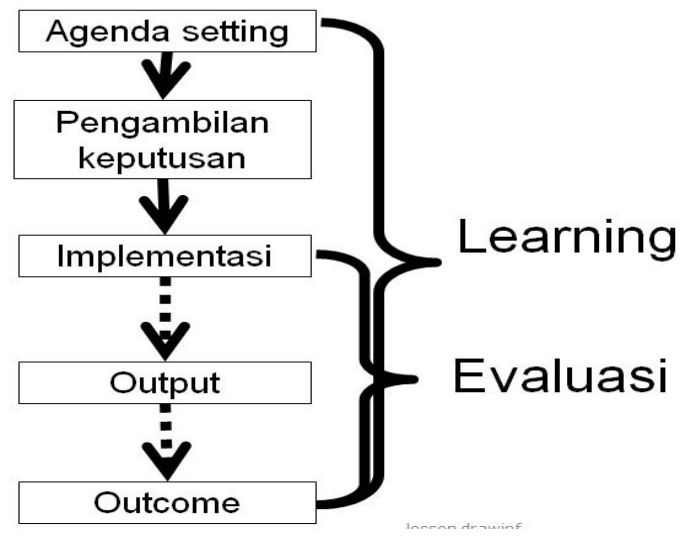

Bennet dan Howlett (1992, 276-278) menawarkan tiga tipe learning ketika melakukan review literatur dan mengaitkannya dengan perubahan kebijakan, yaitu government learning, lesson drawing, dan social learning. Ketiga tipe ini didapatkan berdasarkan tiga struktur pertanyaan yang dieksplorasi dalam literatur, yaitu : siapa yang melakukan pembelajaran, apa yang dipelajari dan apa efeknya. Hasilnya government learning dilakukan oleh pegawai negeri, mempelajari tentang proses kebijakan dan mengakibatkan perubahan organisasional. Lesson drawing dilakukan oleh jaringan kebijakan, mempelajari mengenai instrumen kebijakan dan mengakibatkan perubahan program. Social learning dilakukan oleh komunitas kebijakan, mempelajari mengenai ide dan mengakibatkan perubahan paradigma. Namun pembedaan ini tidak kaku. Pegawai negeri bisa mengalami lesson drawing seperti para jejaring kebijakan mengalami perubahan organisasi selain perubahan program. Dengan demikian tipe ini tidak memberikan batasan yang kaku bahwa government learning, lesson drawing atau social learning harus sesuai dengan pakemnya.

Kemp dan Weehuizen $(2005,8)$ membedakan pembelajaran menjadi tiga tipe: instrumental learning, conceptual/problem learning, dan social learning. Instrumental learning adalah technical learning tentang instrumen, yaitu bagaimana instrumen dikembangkan untuk mencapai tujuan yang ditetapkan. Conceptual learning atau problem learning melihat sesuatu dari sudut pandang yang berbeda sehingga menghasilkan problematisasi yang berbeda. Disebut juga conceptual learning karena biasanya terjadi juga pengembangan atau adopsi konsep baru, prinsip dan gambaran kebijakan. Social learning mempelajari mengenai nilai, hal yang lebih luhur seperti norma, tanggung jawab, tujuan dan membungkus isu dalam bentuk hubungan sebab akibat yang dipilih untuk dilihat. Garis pembeda antara conceptual learning dan social learning tidak selalu jelas.

Argyris (1986) dalam Kemp dan Weehuizen $(2005,17)$ menemukan bahwa seringkali terjadi konflik antara apa yang mereka katakan dan bukti dari apa yang mereka lakukan (teori yang diekspos vs teori yang dilakukan). Meskipun orang seringkali mengklaim bahwa mereka telah melakukan pembelajaran dan 
mempraktikkannya seringkali tidak tampak dalam perilaku mereka. Dalam menganalisis dokumen, Kemp dan Weehuizen $(2005,17)$ menawarkan untuk membuat pembedaan antara: subjek yang dibuat dan diantarkan secara internal seperti memo; subjek yang dibuat secara internal tetapi diantarkan secara eksternal seperti dokumen kebijakan; dan subjek yang dibuat secara eksternal tetapi diantarkan secara internal seperti hasil kajian oleh pihak ketiga.

Selain tipe pembelajaran, yang tidak kalah penting adalah memahami cara para pembuat kebijakan dalam melakukan pembelajaran. Kemp dan Weehuizen $(2005,18)$ mengenalkan tiga cara pembelajaran. Cara yang pertama yaitu dengan pengalaman tanpa studi khusus (learning by doing). Pengalaman tanpa studi khusus ini merupakan pembelajaran langsung, yang berarti para pembuat kebijakan melakukan pembelajaran dari pengalaman sendiri secara langsung. Cara pembelajaran yang kedua adalah melalui pengamatan terhadap kebijakan lain (lesson drawing). Lesson drawing ini dipromosikan oleh Rose (1991). Lesson drawing ini adalah pembelajaran dari kebijakan yang lain melalui pengamatan. Cara pembelajaran yang ketiga adalah pembelajaran dari studi komisi khusus. Cara pembelajaran dengan studi dari komisi khusus ini adalah merupakan pembelajaran tidak langsung.

Policy learning bisa terjadi karena paksaan (koersif) atau sukarela (voluntary). Lebih lanjut Rose $(2005,81)$ mengklasifikasi bentuk kebijakan policy learning menjadi beberapa bentuk, antara lain fotokopi, mengkopi, adaptasi, hibrid, sintesis, inspirasi disiplin, dan imitasi selektif. Fotokopi merupakan perumusan program dari satu sumber contoh. Fotokopi ini membuat fotokopi program yang sama persis hanya dengan perubahan yang minimal seperti nama institusi dan tempat serta tanggal. Sedangkan mengkopi termasuk program yang memakai satu sumber contoh. Mengkopi ini menduplikasi hampir semua elemen program yang telah berhasil di tempat lain. Mengkopi ini mirip dengan fotokopi namun disertai dengan variasi dalam detail minor agar mengakomodasi perbedaan konteks dan preferensi dalam melakukan mengkopi.

Untuk adaptasi, ini merupakan program yang memakai satu sumber contoh. Adaptasi ini mengubah detail desain program dimana tanpa menghilangkan elemen utama program. Sementara itu, bentuk hibrid digunakan untuk mengambil pelajaran dari dua atau lebih program lain. Hibrid mengkombinasikan elemenelemen dari program-program yang memiliki tujuan sama yang berada dalam wilayah yurisdiksi yang berbeda. Sedangkan sintesis itu mengkombinasikan elemen-elemen yang familiar dari program-program dengan tujuan yang sama dengan satu cara yang baru. Bentuk inspirasi disiplin itu merespon pendorongpendorong inspirasi suatu program di mana saja dengan membuat sebuah program baru yang tidak seperti program sumbernya. Dan yang terakhir adalah imitasi selektif. Imitasi selektif ini tidak menggunakan suatu model sumber secara disiplin. Imitasi yang dilakukan hanya selektif dengan menggunakan suatu pembelajaran yang perlu saja untuk membuktikan bahwa pembuat kebijakan telah mengambil pelajaran dan meninggalkan bagian-bagian penting model sumber yang berisiko mengakibatkan biaya politik. 
Policy learning merupakan proses pembelajaran kebijakan sehingga melahirkan kebijakan publik yang baru dan yang berbeda dari sebelumnya. Proses ini secara sekilas tampak sebagai proses administratif, namun ketika melihat sifat dasar dari birokrasi yang enggan akan perubahan, maka proses perubahan ini adalah efek dari relasi kuasa di antara para aktor yang terlibat. Di sinilah letak politisnya. Siapa mempengaruhi apa dan dengan cara bagaimana. Dari sini akan terlihat relasi kuasa antar aktor dan bagaimana pengaruh pembelajaran untuk perubahan kebijakan itu dilakukan.

\section{Kebijakan Penanggulangan Kemiskinan Daerah}

Dalam konteks kebijakan penanggulangan kemiskinan, definisi tentang kemiskinan merupakan bagian penting untuk dipahami. Lynstad dalam Jatmiko, Hanif dan Zakiyah (2010, 4-5) mendefinisikan bahwa kemiskinan sangat erat dengan kapasitas sumber daya yang dimiliki oleh seseorang. Seseorang yang disebutkan miskin pada dasarnya merupakan orang yang memiliki kekurangan sumber daya material ketika akan terlibat dalam aktivitas-aktivitas sosial yang ada atau seseorang yang tidak memiliki kesempatan untuk memperoleh keuntungan atau standar hidup yang layak menurut lingkungan dia tinggal. Dengan kata lain, gagal untuk bisa terlibat dalam aktivitas normal dan memperoleh keuntungan dikarenakan oleh ketidakcukupan sumberdaya material.

Ada tiga dimensi kemiskinan, yaitu natural, kultural dan struktural (Sulistiyani 2004). Kemiskinan natural ialah suatu kondisi keterbatasan secara alamiah seperti kondisi alam yang tak menguntungkan sehingga membatasi usaha suatu komunitas untuk memenuhi kebutuhan hidupnya. Kemiskinan kultural adalah suatu kondisi miskin yang dihadapi oleh suatu komunitas disebabkan karena faktor budaya. Sedangkan kemiskinan struktural merupakan kemiskinan yang melanda komunitas karena dijebak oleh struktur yang dibangun oleh sekelompok orang yang mengambil keuntungan dari struktur tersebut. Ketika berbicara mengenai kebijakan penanggulangan kemiskinan daerah, maka kemiskinan yang dibayangkan adalah kemiskinan struktural dimana pemerintah memiliki kewenangan untuk mendistribusikan sumber daya publik dengan kebijakan yang selektif (Winnick 1996).

Dalam kebijakan penanggulangan kemiskinan ini terdapat beberapa konsep. Diantaranya adalah konsep pro poor budgeting. Konsep ini merupakan politik baru reformasi anggaran di Indonesia, yang menjadi kerangka pengarusutamaan anggaran negara dan daerah untuk penanggulangan kemiskinan. Selain didorong oleh demokratisasi anggaran, pro poor budgeting merupakan bagian dari kebijakan yang berpihak pada kaum miskin. Secara konseptual, pro poor policy adalah tindakan politik yang bertujuan mengalokasikan hak-hak dan sumber daya kepada individu, organisasi, dan wilayah yang termarginalisasi oleh pasar dan negara.

Konsep lain dalam pengalokasian sumber daya publik untuk kelompok masyarakat tertentu dalam penanggulangan kemiskinan adalah need based approach dan asset based approach (UNHABITAT 2008). Dalam pengalokasian sumber daya dengan konsep need based approach memerlukan standar untuk mendefinisikan dan melakukan assesmen terhadap kebutuhan komunitas. 
Pemerintah harus mengembangkan berbagai mekanisme dan institusi untuk mengidentifikasi dan memprioritaskan kebutuhan lokal seperti perumahan, kesehatan, pendidikan dan pekerjaan. Kritik dalam pendekatan ini meliputi isu ekuitas dan efisiensinya serta persepsi tentang kemiskinan yang berbeda-beda. Kebijakan need based appoach ini lebih berfokus pada apa yang tidak dipunyai oleh kelompok miskin tersebut dan berusaha dipenuhi pemerintah.

Sebaliknya kebijakan asset based appoach berfokus kepada apa yang dimiliki oleh kelompok tersebut. Asset based approach tidak butuh untuk menguantifikasi kebutuhan. Tetapi asset based approach bertujuan untuk memberanikan sikap berani berubah dan pembangunan kapasitas antar anggota masyarakat. Asset based approach mencari dan menguantifikasi aset yang ada di komunitas, baik aset terukur maupun tidak terukur daripada mencari kekurangannya. Bagi pembuat kebijakan, aset komunitas berguna karena sebagai milik bersama memberikan manfaat bagi masyarakatnya melalui berbagai cara. Aset komunitas meliputi modal fisik dan insfrastruktur (bangunan, jalan, ruang publik seperti taman dan pasar), modal finansial dan ekonomi, dan modal politik dan sosial yang berkaitan dengan kepemimpinan lokal dan jaringan sosial informal.

\section{Gunung Kidul dan Persoalan Kemiskinan}

Kabupaten Gunungkidul merupakan salah satu kabupaten di Daerah Istimewa Yogyakarta yang identik dengan stigma kemiskinan. Ketika mendengar kata Gunungkidul, orang seringkali mengasosiasikan dengan desa, merantau, kekeringan dan kemiskinan. Cerita yang sering terdengar, setiap hari raya lebaran para perantau pulang kampung dan membawa remitansi yang lebih besar daripada APBD yang dikelola Pemda. Di setiap titik strategis jalan raya banyak spanduk bertuliskan "Ayo Merantau". Para perantau yang sukses di perantauan selalu mengajak teman-teman atau kerabat mereka untuk merantau ke kota-kota besar guna mengadu dan mencari nasib lebih baik, karena kondisi di kampung begitu terbatas dan miskin. Datangnya musim kemarau juga selalu menghadirkan ancaman kekeringan bagi warga Gunungkidul. Ketika kemarau warga harus membeli air sejumlah dua puluh tiga ribu rupiah per meter kubiknya. Selain itu juga seringkali terjadi kanibalisasi ternak, sehingga terkenal "sapi makan sapi". Para peternak menjual sapi untuk membeli pakan guna merawat sapi-sapi mereka yang lain (IRE 2011, 1).

Kemiskinan di Kabupaten Gunungkidul ini menjadi perhatian banyak pihak, baik pemerintah pusat, daerah maupun swasta. Pemerintah pusat selalu menjadikan Kabupaten Gunungkidul sebagai lokasi program-program penanggulangan kemiskinan. Bahkan, menurut Sutoro Eko (IRE 2011, 4), "Jakarta selalu menyediakan slot anggaran untuk mendukung penanggulangan kemiskinan Gunungkidul sekalipun tanpa dilobby". Pemerintah Kabupaten Gunungkidul juga selalu menetapkan penanggulangan kemiskinan sebagai prioritas utama pembangunan daerah. Berbagai program penanggulangan kemiskinan juga telah diimplementasikan. Kemudian berbagai dana corporate social responsibility (CSR) dari BUMN dan swasta serta non-governmental organization (NGO) banyak yang masuk ke Kabupaten Gunungkidul (IRE 2011, 4). 
Namun demikian, semua perhatian dari berbagai pihak ini belum mampu membuat Kabupaten Gunungkidul bangkit dari kemiskinan. Kabupaten Gunungkidul masih sangat lekat dengan stigma kemiskinan. Angka kemiskinan di Kabupaten Gunungkidul masih sangat tinggi. Kemiskinan ini selalu dipandang sebagai masalah utama oleh Pemerintah Kabupaten Gunungkidul, sehingga hal ini yang membuat Pemerintah Kabupaten Gunungkidul sangat serius dalam merumuskan kebijakan untuk penanggulangan kemiskinan daerahnya. Penanggulangan kemiskinan selalu ditempatkan dalam prioritas utama pembangunan di Kabupaten Gunungkidul.

Penelitian mengenai kemiskinan dan kebijakan penanggulangan kemiskinan di Kabupaten Gunungkidul sudah dilakukan berbagai pihak. Ada beberapa hasil kajian dan penelitian yang digunakan sebagai bahan pembuatan kebijakan pemerintah, namun tidak semuanya diambil pelajaran dalam membuat kebijakan penanggulangan kemiskinan. Oleh karena itu, menarik untuk mengkaji mengapa Pemerintah Kabupaten Gunungkidul mengambil pelajaran dari suatu kajian dan tidak mengambil pelajaran dari kajian yang lain, padahal kajian-kajian tersebut sama-sama menghasilkan rekomendasi kebijakan yang menjadi alternatif solusi terhadap masalah utama di Gunungkidul. Dalam hal inilah policy learning bekerja. Proses policy learning meliputi pembelajaran yang dilakukan oleh pemerintah dan keputusan memasukkan pembelajaran tersebut dalam kebijakan yang dibuat oleh pemerintah.

\section{Metode}

Kajian ini adalah penelitian kualitatif dengan menggunakan studi kasus. Kasus yang diangkat berasal dari proses reformulasi kebijakan penanggulangan kemiskinan daerah di Kabupaten Gunungkidul 2012-2015. Pengambilan data dilakukan dengan mengunakan wawancara mendalam kepada para aktor yang terlibat dalam proses penyusunan kebijakan. Data ini juga dicari di lapangan melalui observasi lokasi pilot project kerjasama kebijakan dan penelusuran data sekunder untuk menemukan fakta-fakta administratif dan dikonfirmasikan kepada pihak terkait melalui wawancara. Analisis data dilakukan dengan analisis kualitatif menggunakan kerangka teori policy learning.

Kebijakan yang menjadi fokus adalah kebijakan penanggulangan kemiskinan dalam kurun waktu 2007-2011. Batasan waktu 2007-2011 ini disesuaikan dengan dokumen resmi kebijakan penanggulangan kemiskinan daerah yang diformulasikan dalam Strategi Penanggulangan Kemiskinan Daerah (SPKD) Kabupaten Gunungkidul 2007-2011. SPKD ini merupakan pemandu arah semua program penanggulangan kemiskinan yang ada di Gunungkidul (Bappeda 2007, 1). Selain dokumen SPKD, ada dokumen Rencana Pembangunan Jangka Menengah Daerah (RPJMD) sebagai pemandu arah pembangunan. Dokumen RPJMD ini juga memuat tentang kebijakan penanggulangan kemiskinan daerah di dalamnya. Kebijakan penanggulangan kemiskinan daerah juga dilihat dari perspektif para pembuat kebijakan di Kabupaten Gunungkidul tentang penanggulangan 
kemiskinan daerahnya, untuk mengetahui bagaimana konsep pembuat kebijakan tentang penanggulangan kemiskinan di Kabupaten Gunungkidul.

\section{Hasil dan Pembahasan}

\section{Kegagalan Kebijakan Penanggulangan Kemiskinan Daerah}

Kebijakan penanggulangan kemiskinan daerah di Gunungkidul secara makro terdapat di Rencana Pembangunan Jangka Menengah Daerah. Kebijakan tersebut secara khusus diwujudkan dalam satu dokumen Strategi Penanggulangan Kemiskinan Daerah/SPKD. SPKD ini mulai dibuat sejak tahun 2007 sebagai amanat dari peraturan presiden nomor 54 tahun 2005. SPKD pertama yang dirumuskan adalah SPKD 2007-2011, dibuat oleh Tim Koordinasi Penanggulangan Kemiskinan Daerah/TKPKD, diketuai oleh Wakil Bupati dan Bappeda berperan sebagai kepala sekretariatnya. Dalam proses penyusunannya, TKPKD mendapatkan pendampingan dari Tim Koordinasi Penanggulangan Kemiskinan Nasional/TKPKN.

Dokumen pertama yang dilacak mengenai kebijakan penanggulangan kemiskinan daerah di kabupaten Gunungkidul adalah dokumen Rencana Pembangunan Jangka Menengah Daerah (RPJMD) 2005-2010. RPJMD merupakan penjabaran visi dan misi kepala daerah terpilih ke dalam rencana pembangunan selama lima tahun. Pada tahun 2005 melalui pemilukada langsung, terpilih pasangan Suharto-Badingah sebagai kepala daerah dan wakil kepala daerah. Bupati dan Wakil Bupati terpilih ini kemudian menyusun RPJMD sebagai acuan dalam melakukan pembangunan selama periode kekuasaannya.

Pasangan Suharto-Badingah memilih strategi penanggulangan kemiskinan melalui jargon desa sebagai pusat pertumbuhan. Strategi ini prinsipnya hendak "memerangi" kemiskinan yang dimulai dari desa. Selama lima tahun kepemimpinannya (2005-2010), desa sebagai pusat pertumbuhan menjadi pijakan dasar kebijakan Bupati Suharto. Bupati meyakini bahwa kebijakan daerah yang bias kota justru akan memicu masalah baru berupa pengangguran, urbanisasi, dan pengurangan penduduk di desa.

Dari dokumen RPJMD dan konsep Bupati, dapat diketahui bahwa penanggulangan kemiskinan merupakan prioritas dalam pembangunan di Gunungkidul. Keempat arah kebijakan pembangunan yang tercantum dalam RPJMD juga bermuara pada penyelesaian masalah kemiskinan. Sebagai strategi, penanggulangan kemiskinan daerah mengambil desa sebagai dasar untuk penanggulangan kemiskinan. Selain dari RPJMD, secara lebih khusus pemerintah menyusun strategi penanggulangan kemiskinan daerah dalam wujud dokumen strategi penanggulangan kemiskinan daerah (SPKD) tahun 2007-2011. Strategi penanggulangan kemiskinan daerah (SPKD) merupakan pedoman dan arah kebijakan program penanggulangan kemiskinan di Gunungkidul (Bappeda 2007).

Jika dalam RPJMD penanggulangan kemiskinan dilakukan dengan program kegiatan yang mensejahterakan rakyat, dan kemudian Bupati memiliki konsep penanggulangan kemiskinan dengan menempuh kebijakan sosial dan pembangunan desa, selanjutnya dilihat penanggulangan kemiskinan dalam 
dokumen SPKD. Dalam dokumen SPKD 2007-2011, disebutkan bahwa visi penanggulangan kemiskinannya adalah terwujudnya pemenuhan hak-hak dasar yang menjamin harkat dan martabatnya sebagai manusia bagi masyarakat kabupaten Gunungkidul.

Pada tahun 2005, Kementerian Pembangunan Daerah Tertinggal (KPDT) memberikan predikat "daerah tertinggal" kepada Kabupaten Gunungkidul. Tiga tahun berikutnya, pada tahun 2008, KPDT memberikan penghargaan kepada 28 Kabupaten yang "mentas" dari predikat tertinggal, namun Kabupaten Gunungkidul tidak termasuk di dalamnya (IRE, 2011). Kemudian berdasarkan data susenas (BPS) proporsi penduduk miskin di Kabupaten Gunungkidul sejak tahun 20072011 mengalami penurunan dari 28,9\% di tahun 2007 menjadi 22,05\% di tahun 2010. Namun pada tahun 2011 penduduk miskin mengalami kenaikan 0,98\% sehingga menjadi 23,03\%. Angka ini lebih tinggi dari angka kemiskinan provinsi DIY yang 16\% dan angka kemiskinan nasional yang sekitar 13,33\%. Apabila dilihat indeks kedalaman kemiskinan dan indeks keparahan kemiskinan, Indeks kedalaman kemiskinan di Kabupaten Gununkidul mengalami penurunan dari 5,13 di tahun 2008 menjadi 1,16 di tahun 2011 yang mengindikasikan bahwa ada penurunan tingkat pengeluaran penduduk yang semakin menjauh dari garis kemiskinan. Sedangkan indeks keparahan kemiskinan di Kabupaten Gunungkidul selama tiga tahun mengalami penurunan, dari 1,36 di tahun 2008 ke 0,43 di tahun 2010. Pada tahun 2011 terjadi kenaikan sebesar 0,41 yang mengindikasikan bahwa ada potensi peningkatan ketimpangan pengeluaran penduduk miskin (Bappeda 2012).

Pertumbuhan ekonomi Kabupaten Gunungkidul termasuk kategori moderat disertai dengan trend fluktiatif. Pertumbuhan di tahun 2011 sebesar 7,88\% atau lebih kecil dibanding tahun 2009 ke tahun 2010 sebesar 10,63\%. Pertumbuhan ini cenderung lambat dalam penurunan angka kemiskinan. Kesejahteraan masyarakat secara umum belum sampai derajat kesejahteraan yang layak karena tingkat pendapatan masyarakat lebih rendah daripada upah minimum regional provinsi DIY tahun 2012 yang sebesar Rp. 892.660,00 (Bappeda 2012). Hal ini menunjukkan bahwa kebijakan penanggulangan kemiskinan daerah di Kabupaten Gunungkidul masih belum menunjukkan hasil yang memuaskan.

Untuk lebih memudahkan penjelasan mengenai kegagalan kebijakan penanggulangan kemiskinan di Gunungkidul, berikut disajikan kritik dan rekomendasi mengenai kegagalan kebijakan penanggulangan kemiskinan. Kritikkritik ini disajikan dengan klasifikasi yang lebih sistematis menurut cara pandangnya. Kritik terhadap kebijakan penanggulangan kemiskinan di Kabupaten Gunungkidul yang pertama adalah secara politis. Menurut penelitian IRE (2011), komitmen Bupati dalam penanggulangan kemiskinan daerah yang juga tercermin dalam visi dan misi Bupati dalam penanggulangan kemiskinan dan pembangunan berbasis desa hanyalah "monumen" administrasi yang terdokumentasikan di kantor-kantor pemerintahan. "Kemewahan" visi misi dan komitmen Bupati ternyata sulit dijadikan sebagai pandu arah untuk merumuskan kebijakan, program dan kegiatan penanggulangan kemiskinan yang efektif. Sampai akhir kepemimpinan Bupati sulit dilacak jejak dan pencapaian kerjanya. Visi, misi dan 
strategi penanggulangan kemiskinan yang diformulasikan Bupati hanya sebatas jargon yang enak dibicarakan dan ditulis namun terasa hambar ketika dilaksanakan. Dengan kata lain, penanggulangan kemiskinan hanyalah lipstik Bupati dalam penyelenggaraan pemerintah daerahnya.

Penelitian Ma'arif Institute (2007) sejalan dengan penelitian IRE (2011) menemukan bahwa alokasi anggaran program penanggulangan kemiskinan presentasenya sangat kecil, tidak sampai 3\% per tahun padahal penanggulangan kemiskinan selalu menjadi prioritas pembangunan. Hal ini menggambarkan sikap ambigu pemerintah Gunungkidul dalam penanggulangan kemiskinan.

Kritik berikutnya adalah secara administratif. Secara administratif dokumen Strategi Penanggulangan Kemiskinan Daerah (SPKD) tahun 2007-2011 yang disusun oleh Pemerintah Kabupaten Gunungkidul yang juga merupakan arah dan panduan bagi seluruh program penanggulangan kemiskinan bukanlah gambaran riil intisari permasalahan dan kebutuhan orang miskin di Gunungkidul. Hal ini karena SPKD disusun dengan tujuan sebagai prasyarat administrasi proyek. Sebagai persyaratan administrasi suatu proyek, patut dipertanyakan proses penyusunan dan kualitas yang disusunnya. Sebagai dokumen resmi dan penting bagi upaya menanggulangi kemiskinan, seharusnya proses penyusunannya berpijak pada suara-suara orang miskin. Pun demikian isi yang diformulasikan seharusnya menyajikan permasalahan dan kebutuhan orang miskin secara faktual. Dokumen SPKD seharusnya disusun secara partisipatif melibatkan orang-orang miskin, secara teknokratis dirumuskan orang-orang kompeten, dan secara politis menjadi komitmen bersama seluruh pemangku kepentingan daerah (IRE 2011).

Secara kelembagaan, desain dan kapasitas kelembagaan dalam penanggulangan kemiskinan di Gunungkidul juga terdapat permasalahan. Permasalahan pertama adalah berubah-ubahnya struktur Tim Koordinasi Penanggulangan Kemiskinan (TKPKD) karena mengikuti perubahan aturan pemerintah pusat, sehingga membuat TKPKD tidak bekerja secara optimal. Belum bekerja, sudah berganti struktur.

Selanjutnya adalah kapasitas kepemimpinan dalam melakukan koordinasi masih lemah. Posisi wakil bupati sebagai ketua tim TKPKD, sebagaimana amanat Perpres No. 54 tahun 2005, dalam kenyataannya tidak cukup otoritatif dalam memobilisasi birokrasi dalam rangka membangun koordinasi penanggulangan kemiskinan. Ego sektoral SKPD masih sangat kuat. Masing-masing SKPD masih berkecenderungan untuk melaksanakan masing-masing program kegiatannya tanpa merasa perlu berkoordinasi dengan SKPD yang lain. Hingga saat ini TKPKD belum mampu menjadi sarana yang efektif untuk memastikan koordinasi program dan meminimalisasi tumpang tindih program atau kegiatan antar SKPD (Jatmika, Hanif, dan Zakiyah 2010). Secara teknis, koordinasi dan integrasi program penanggulangan kemiskinan masih belum efektif. Banyak program penanggulangan kemiskinan yang berjalan sendiri-sendiri, baik program pusat maupun program daerah. Pola yang digunakan dalam anggaran masih fragmented budget, sehingga seperti membagi-bagikan uang receh pada masyarakat (IRE 2011). 
Permasalahan lainnya adalah tidak ada sistem informasi dan database kemiskinan terpadu. Hampir seluruh SKPD punya program penanggulangan kemiskinan tapi basis data kemiskinan yang dimiliki berbeda-beda sehingga data antar SKPD tidak pernah sinkron. Adanya perbedaan persepsi tentang definisi dan cara pandang kemiskinan menjadi masalah tersendiri. Pemerintah memang sudah menegaskan bahwa indikator kemiskinan yang dipakai adalah data dari BPS. Namun data BPS sendiri seringkali tidak valid dan akurat terutama untuk datadata mikro. Seringkali pula indikator-indikator tersebut tidak sesuai dengan konteks lokal yang ada (Jatmika, Hanif, dan Zakiyah 2010).

Kemudian upaya Analisa Kemiskinan Partisipatif yang merupakan ide untuk menangani masalah teknis ini belum berjalan secara optimal. Tidak ada dukungan anggaran yang memadai untuk melakukan AKP. Pada saat yang sama tidak ada Juklak dan Juknis yang sifatnya lebih instrumentatif namun terpadu yang menjadi panduan analisa kemiskinan di daerah. Forum-forum perencanaan yang ada juga tidak terpadu. Masing-masing pemangku kepentingan memiliki forum-forum perencanaan program penaggulangan kemiskinan yang berjalan sendiri-sendiri. Misalkan forum musrembang PNPM mandiri, forum PNPM Mandiri perkotaan, Musrembang untuk APBD (Jatmika, Hanif, dan Zakiyah 2010).

Secara substansi, konsep penanggulangan kemiskinan yang dimiliki oleh elit negara adalah masih memandang sasaran kemiskinan sebagai beban dan objek. Desa sebagai tempat masyarakat tinggal masih dipandang sebagai objek pembangunan dan beban berat bagi negara. Padahal apabila mau diubah sudut pandang, desa bisa menjadi aset dan kekuatan dalam penanggulangan kemiskinan (IRE 2011). Sejalan dengan ini, pemerintah Gunungkidul juga dikritik terkait dengan model penanggulangan kemiskinan dengan Community Driven Development (CDD) yang bergeser menjadi Money Driven Development (MDD). ketika pemerintah dalam melakukan program pembangunan hanya mengandalkan uang dan memobilisasi massa untuk melakukan program pembangunan.

\section{Policy Learning dalam Reformulasi Kebijakan Penanggulangan Kemiskinan}

Reformulasi kebijakan penanggulangan kemiskinan daerah di Gunungkidul dilakukan dengan penyusunan SPKD 2012-2015 sebagai kelanjutan dari SPKD 2007-2011. Proses penyusunan SPKD 2012-2015 inilah yang terdapat policy learning di dalamnya. Argumentasi terjadinya policy learning dalam reformulasi kebijakan penanggulangan kemiskinan daerah secara sederhana ditandai dengan adanya perubahan kebijakan. Kebijakan penanggulangan kemiskinan yang diwujudkan dalam SPKD 2012-2015 secara normatif disusun oleh TKPKD, terdiri dari lintas SKPD, diketuai oleh wakil bupati dan dikoordinasi oleh Bappeda. Namun, dalam praktiknya disusun oleh tim yang terdiri dari lintas SKPD bersama dengan Institute for Research and Empowerment/IRE Yogyakarta dan Institute for Development and Economic Analysis/Perhimpunan IDEA. Tanggung jawab penyusunan SPKD ini secara normatif di TKPKD, namun secara faktual berada di Bappeda, khususnya Bidang Pemerintahan dan Sosial Budaya, sebagai koordinator penyusunan kegiatan. 
Secara administratif, perubahan kebijakan penanggulangan kemiskinan daerah diperlukan karena dokumen kebijakan sebelumnya habis masa berlakunya. SPKD 2012-2015 merupakan amanah dari Perpres No 15 Tahun 2010 yang menginstruksikan pemerintah daerah untuk menyusunnya (Priyanto Madya, Wawancara, 21 Juli, 2013). Secara substantif SPKD ini perlu disusun karena penanggulangan kemiskinan butuh cetak biru yang terdapat koordinasi program SKPD. Dengan pertimbangan bahwa penanggulangan kemiskinan adalah program yang cross cutting, semua isu saling berkaitan, baik isu pendidikan, kesehatan, ekonomi, maupun lainnnya, sehingga memerlukan dokumen yang memfokuskan program-program tersebut (Sri Suhartanta, Wawancara, 24 April, 2013).

Proses penyusunan dokumen ini diawali dari penelitian bersama antara IRE dan pemerintah Gunungkidul pada tahun 2011 (yang diwakili oleh Bappeda). Penelitian ini bertema penanggulangan kemiskinan dan pembangunan desa. Semua biaya penelitian disediakan oleh IRE. Posisi yang ditawarkan oleh IRE kepada pemerintah adalah sama-sama sebagai peneliti, dengan syarat menghasilkan ide kebijakan yang implementatif (Borni, Wawancara, 1 Oktober, 2013). Hasil penelitian ini diwujudkan dalam buku "Mempertemukan Dua Hulu, pelajaran desentralisasi fiskal dan penanggulangan kemiskinan dari Gunungkidul." Kerja sama tersebut kemudian dilanjutkan dengan penyusunan SPKD pada tahun 2012. Konsep SPKD 2012-2015 menggunakan referensi review konsep SPKD 2007-2011 dan hasil penelitian IRE-Pemerintah Gunungkidul.

Ketika mereformulasi sebuah kebijakan, secara normatif pastilah melihat kebijakan yang lama. Hal ini merupakan norma dalam menyusun ulang sebuah kebijakan, yaitu dengan melihat dan mengambil pelajaran dari kebijakan yang lama. Sama seperti yang diungkapkan Hall $(1993,277)$ bahwa faktor pertama yang mempengaruhi policy learning adalah kebijakan sebelumnya. Dari SPKD 20072011 ini didapatkan pelajaran bahwa program pemerintah pusat harus diacu. Aturan-aturan yang diberlakukan pemerintah pusat harus dipenuhi. Penyusunan SPKD 2012-2015 harus sesuai dengan Perpres nomor 15 tahun 2010 dan sesuai dengan strategi nasional penanggulangan kemiskinan (SNPK) yang didesain oleh pemerintah pusat.

Pembelajaran yang dilakukan oleh pemerintah Gunungkidul dari kebijakan yang lama dalam setiap tahapan kebijakan dapat digambarkan dalam bagan berikut : 
Bagan 2. Pembelajaran dari SPKD 2007-2011

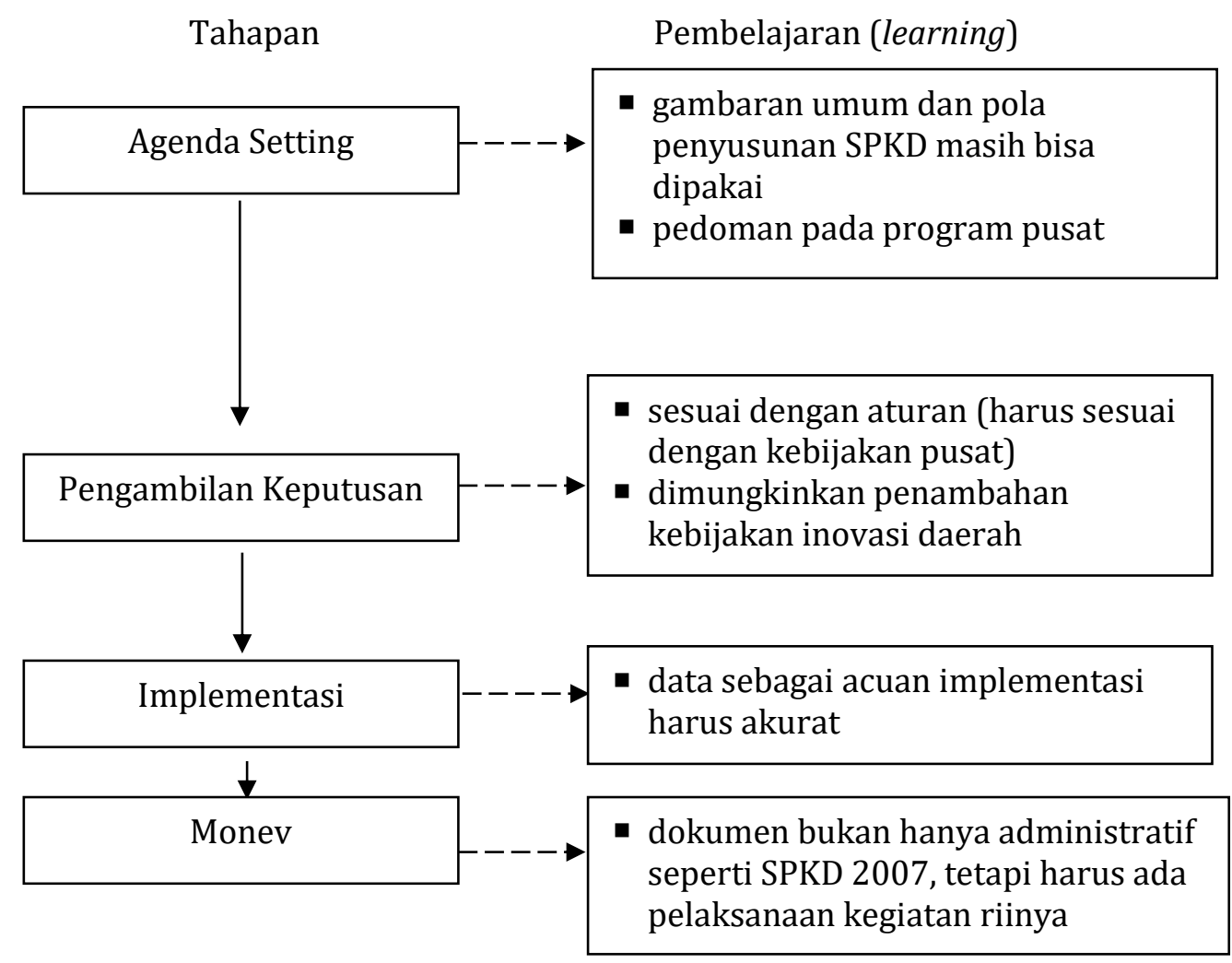

Dari kebijakan yang lama (SPKD 2007-2011), dalam proses formulasi kebijakan pemerintah mengambil pelajaran bahwa formulasi kebijakan harus sesuai dengan peraturan perundang-undangan yang berlaku. Sehingga formulasi kebijakan penanggulangan kemiskinan daerah harus mengikuti aturan bahwa regulasi daerah harus selaras dengan regulasi pusat. Regulasi yang ada di pusat menyatakan bahwa penyusunan kebijakan penanggulangan kemiskinan daerah merupakan kewajiban bagi pemerintah daerah melalui Peraturan Presiden No. 15 tahun 2010 yang menyatakan bahwa pemerintah daerah harus membentuk Tim Koordinasi Penanggulangan Kemiskinan Daerah (TKPKD) dan menyusun Strategi Penanggulangan Kemiskinan Daerah (SPKD) di masing-masing daerah.

Dengan demikian mau tidak mau kebijakan penanggulangan kemiskinan daerah di Kabupaten Gunungkidul yang diwujudkan dalam dokumen SPKD harus mengacu pada Strategi Nasional Penanggulangan Kemiskinan (SNPK). Dengan demikian salah satu sumber pembelajaran dalam perumusan kembali SPKD 20122015 adalah Strategi Nasional Penanggulangan Kemiskinan (SNPK) yang disusun oleh pemerintah pusat. Pembelajaran yang didapat dari SNPK adalah bahwa penanggulangan kemiskinan daerah harus meng-copy empat strategi yang digunakan pemerintah pusat dalam penanggulangan kemiskinan. Hasil penelusuran dari dokumen SPKD 2012-2015 dan hasil wawancara dengan Priyanto Madya didapatkan bahwa, empat strategi utama percepatan penanggulangan kemiskinan yang digariskan oleh pemerintah pusat wajib diikuti. 
Dalam SPKD 2012-2015 tertulis bahwa untuk menunjang penanggulangan kemiskinan yang komprehensif dan mewujudkan percepatan penanggulangan kemiskinan dirumuskan empat startegi utama. Strategi-strategi penanggulangan kemiskinan tersebut diantaranya: memperbaiki Program Perlindungan Sosial; meningkatkan Akses Terhadap Pelayanan Dasar; pemberdayaan Kelompok Masyarakat Miskin; dan pembangunan Inklusif. Keempat strategi ini sekaligus penjelasannya dalam dokumen SPKD 2012-2015 sama persis dengan yang tercantum dalam petunjuk penyusunan SPKD yang disusun oleh pemerintah pusat.

Kebijakan penanggulangan kemiskinan daerah kabupaten Gunungkidul 20122015 tidak semata-mata hanya berpijak pada Strategi Nasional Penanggulangan Kemiskinan (SNPK) yang disusun oleh pemerintah pusat. Pembuat kebijakan juga menambahkan inovasi daerah dalam strategi kebijakan penanggulangan kemiskinan daerah Kabupaten Gunungkidul. Inovasi daerah ini merupakan bagian dari strategi penanggulangan kemiskinan daerah yang sesuai dengan potensi dan kemampuan dari Kabupaten Gunungkidul.

Dengan demikian didapatkan informasi bahwa apa yang bisa dipakai dari SPKD yang lama tetap dipakai dalam SPKD yang baru, tidak harus semua baru. Hal ini untuk menghemat tenaga dan waktu, mengingat pekerjaan di Bappeda sangat banyak dan personilnya sedikit. Sedangkan peraturan dan program dari pemerintah pusat harus diacu karena sudah diamanatkan dalam Perpres dan SPKD harus mampu menampung semua program penanggulangan kemiskinan yang masuk di Kabupaten Gunungkidul, baik dari pemerintah pusat, provinsi maupun swasta. Sehingga sesuai aturan dan agar SPKD mampu mewadahi semua program penanggulangan kemiskinan, maka program pemerintah pusat harus dijadikan acuan dalam penyusunan dokumen SPKD.

Sumber pembelajaran lainnya untuk menyusun SPKD 2012-2015 adalah dari hasil riset kolaborasi IRE dan Bappeda kabupaten Gunungkidul. Penggunaan hasil riset ini sebagai sumber penyusunan kebijakan penanggulangan kemiskinan sudah menjadi kesepakatan awal. Kesepakatannya adalah bahwa hasil riset akan menjadi implementasi kebijakan. Penelitian kolaborasi tersebut menunjukkan bahwa pengelolaan desa wisata memberikan konstribusi yang sangat signifikan terhadap pengembangan ekonomi di wilayah desa yang bersangkutan, mulai dari bertambahnya lapangan kerja lokal, terbukanya peluang usaha perdagangan cinderamata maupun makanan. Kondisi yang demikian membuka jalan yang lebih lebar bagi masyarakat desa untuk meningkatkan perekonomiannya sehingga dapat keluar dari masalah kemiskinan. Namun demikian potensi destinasi wisata saat ini baru direspon beberapa desa, terutama desa-desa yang mempunyai aset yang berhubungan dengan potensi alam (pantai, gua dan sungai).

Oleh karena itu, perlu dirumuskan kebijakan penggalian dan pengembangan potensi ekonomi desa-desa lain, sehingga mampu berkembang seperti halnya desa-desa yang sudah tumbuh berdasarkan aset dan potensi yang dimilikinya. Dengan demikian, pemerintah menyadari akan perlunya industrialisasi desa sesuai dengan potensinya. Industrialisasi desa ini diiringi dengan cara pandang penanggulangan kemiskinan dari yang berbasis masalah dan kebutuhan (problem based) ke penanggulangan kemiskinan berbasis potensi/aset (asset based). 
Dalam penelitian yang sama, dihasilkan temuan yang menunjukkan bahwa institusi sosial yang berupa kelembagaan (RT, kelompok organisasi) mapun yang berupa pranata sosial (gotong royong, rosulan, dll) merupakan modal sosial yang unik yang dimiliki masyarakat Gunungkidul dan jarang dimiliki daerah lain. Keberadaan institusi lokal tersebut menjadi bagian dari dinamika lokal dalam mendorong pembangunan, penanggulangan kemiskinan, hingga prakarsa membangun kesejahteraan.

Meskipun keberadaan institusi sosial cukup beragam baik dari segi jumlah, jenis dan distribusinya yang merata di pelosok dusun, akan tetapi sampai saat ini fungsi institusi sosial tersebut masih terkonsentrasi pada kepentingan ikatan sosial (social bonding) saja. Oleh karena itu, perlu dirumuskan kebijakan baru guna menata institusi sosial untuk bisa menjadi suatu energi positif dalam penanggulangan kemiskinan. Institusi lokal dalam bentuk organisasi telah menunjukkan kontribusinya menjadi agen membuka peluang kesempatan kerja bagi warganya, yang muaranya juga akan berdampak pada peningkatan pendapatan keluarga.

Untuk penguatan lembaga kemiskinan, penelitian IRE dan Bappeda ini menemukan bahwa lembaga yang menangani kemiskinan belum ada yang definitif. Tim Koordinasi Penanggulangan Kemiskinan yang merupakan lembaga adhoc belum mampu memerankan fungsi utama sebagai koordinator penanggulangan kemiskinan di daerah. Agar penanggulangan kemiskinan lebih terarah dan bersinergi antar stakeholder terkait, maka revitalisasi TKPD perlu dirumuskan, agar lebih mampu memfungsikan perannya sesuai dengan amanat Perpres Nomor 15 Tahun 2010 dan Permendagri Nomor 43 Tahun 2010. Solusi yang ditawarkan adalah menguatkan lembaga penanggulangan kemiskinan formal yang ada dengan lembaga-lembaga lain baik formal maupun informal untuk bersama-sama melakukan program penanggulangan kemiskinan.

Pembelajaran dari hasil riset ini yang kemudian dicantumkan dalam dokumen SPKD ada tiga hal. Dalam penanggulangan kemiskinan daerah yang pertama diperlukan strategi industrialisasi desa. Kedua dalam penanggulangan kemiskinan perlu penguatan institusi lokal. Ketiga perlu memperkuat kelembagaan dalam penanggulangan kemiskinan daerah. Strategi-strategi ini tidak menimbulkan program maupun kegiatan baru dengan instrumen kebijakan yang baru, namun dalam pelaksanaannya tetap menggunakan program yang lama dengan perubahan konsep dari penanggulangan kemiskinan berbasis masalah menjadi (problem based) menjadi penanggulangan kemiskinan berbasis asset (asset based).

Pembelajaran yang dilakukan oleh Pemerintah Kabupaten Gunungkidul secara keseluruhan dapat digambarkan dalam bagan sebagai berikut: 


\section{Bagan 3. Learning Pemkab Gunungkidul dalam penyusunan SPKD}

Sumber

Pembelajaran (learning)

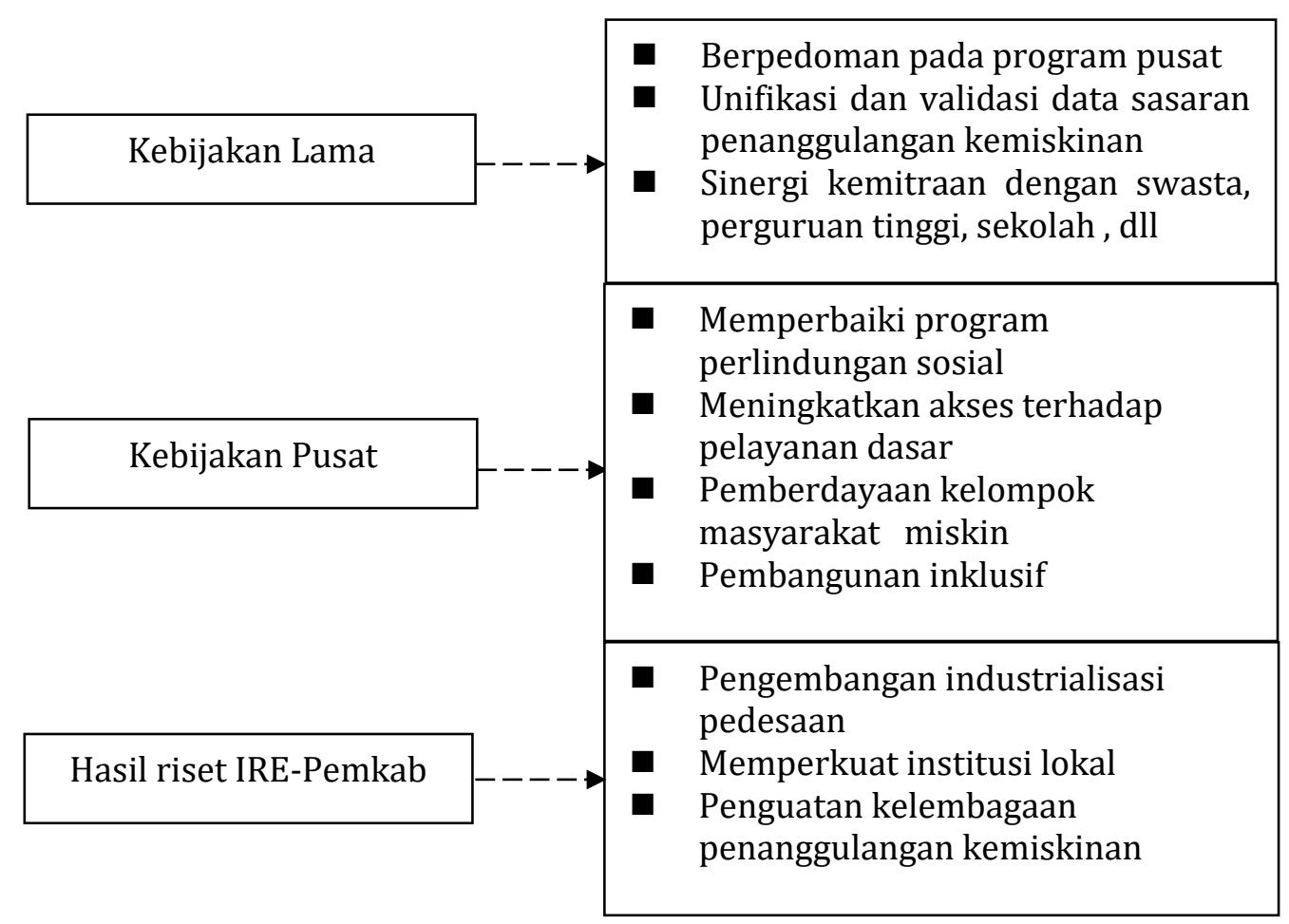

Menurut Sri Suhartanta, Sekretaris Bappeda Kabupaten Gunungkidul, perubahan yang paling menojol dalam SPKD 2012-2015 ini adalah perubahan cara pandang terhadap penanggulangan kemiskinan (Wawancara, 24 April, 2013). Dari bukti-bukti pembelajaran yang dilakukan didapatkan gambaran bahwa pemerintah daerah melakukan conceptual learning dalam reformulasi kebijakan penanggulangan kemiskinan daerahnya. Perubahan mendasar dalam kebijakan penanggulangan kemiskinan daerah di Gunungkidul adalah perubahan cara pandang, dari kemiskinan dilihat sebagai masalah (problem based) menjadi cara pandang potensi (asset based).

Perubahan cara pandang ini kemudian mengantarkan pada perubahan target kelompok pembangunan menjadi berbasis potensi wilayah, tidak lagi hanya berdasarkan usulan masyarakat tanpa mempertimbangkan potensinya. Sementara program-program yang ditawarkan dalam penanggulangan kemiskinan menginduk pada SKPD terkait dan tidak ada perubahan dalam desain implementasi kebijakan. Perubahan yang ada adalah perubahan target kelompok kebijakan, yang pada asalnya kepada siapa saja yang ingin mengakses program, menjadi berdasarkan potensi yang dimiliki oleh daerah. Hal ini menunjukkan hanya terjadi conceptual learning dan tidak terjadi instrumental learning dan social learning dalam reformulasi kebijakan penanggulangan kemiskinan daerah di Gunungkidul. 
Mengapa hanya terjadi conceptual learning dan tidak terjadi instrumental learning dan social learning. Priyanto Madya (Wawancara, 27 Juni, 2013) mengungkapkan bahwa:

"Lebih baik menggunakan program yang sudah ada. Program yang sudah ada disinergikan dan dipertajam. Kalau membuat program baru, malah buat ruwet. Program yang sudah ada aja sudah ruwet, mending yang sudah ada aja ditata lagi. Budget kami kan terbatas, jadi ketika ada usulan baru respon penolakan pasti tinggi. Kami tidak berani coba-coba dengan program yang belum tentu berhasil. Formula lama saja dibenahi dengan program bernafas baru."

Untuk implementasi TKPKD, pemerintah kabupaten juga tidak membuat instrumen kelembagaan baru. Lebih lanjut Priyanto Madya (Wawancara, 27 Juni, 2013) mengungkapkan bahwa :

"Kelembagaan TKPKD kami buat sampai tingkat desa. lembaga untuk urusan kemiskinan cukup dengan satu. Ga bikin lembaga baru yang bikin kisruh. Karena esensinya kerja lembaga itu kan sudah ada. Kerjanya itu-itu saja. Jadi secara substansi sama. Lembaga baru bikin friksi di tingkat bawah. SPKD terimplementasi, tapi perkuat yang sudah ada. Lebih baik jalan realistis daripada jalan belum jelas."

Dari hal tersebut diketahui bahwa tidak terjadinya instrumental dan social learning disebabkan karena karakter dasar birokrasi yang bahwa kalau tidak rusak, jangan diperbaiki (Rose 1991). Para pembuat keputusan seringkali selalu mengikuti strategi tidak melakukan apa-apa. Strategi tidak melakukan apa-apa ini dianggap efisien dan aman. Ketika para pembuat kebijakan menganggap bahwa segala sesuatunya sudah memberikan kepuasan, berarti semuanya sudah berjalan baik seperti yang mereka lihat terakhir kali.

Dalam menerangkan mengenai pembelajaran kebijakan yang dilakukan, Priyanto Madya selalu memberikan contoh-contoh konkrit semisal keberhasilan desa wisata bleberan, gua pindul, pasar buah putat dan pantai baron. Contohcontoh ini sangat dekat dan dikenal bagaimana keberhasilannya oleh pemerintah. Pemerintah juga turut terlibat dalam riset ini secara langsung. Dengan demikian, pemerintah melakukan pembelajaran langsung dengan berkolaborasi dengan lembaga penelitian IRE dalam mencari perbaikan kebijakan. Dalam riset tersebut pemerintah memiliki posisi yang sama sebagai peneliti, sehingga langsung mengalami dan mengambil pelajaran secara langsung dari lapangan.

Namun, pembelajaran ini diduga ada motif lain, bukan karena kebutuhan pembelajaran pemerintah, namun karena interest pemerintah berupa adanya tawaran riset yang sudah jelas biayanya dan "tidak ada salahnya" mengambil pelajaran untuk diimplementasikan dalam kebijakan daerah. Lagipula kebijakan daerah yang dipengaruhi inovasi ini tidak menimbulkan program baru yang memiliki potensi resistensi tinggi dalam penganggaran. 
Mengapa pemerintah mengambil bentuk pembelajaran tertentu, dan tidak menerapkan bentuk pembelajaran yang lainnya dalam reformulasi kebijakan penanggulangan kemiskinan daerah. Berikut penulis mencoba menganalisis faktor-faktor yang mempengaruhi penerapan policy learning dalam kebijakan publik pemerintah daerah berdasarkan konteks kasus reformulasi kebijakan penanggulangan kemiskinan daerah di Kabupaten Gunungkidul.

Faktor pertama yang mempengaruhi penerapan bentuk policy learning adalah peraturan yang mengikat dalam kebijakan itu sendiri. Setiap kebijakan memiliki dasar hukum yang mengikat mengenai kebijakan yang bersangkutan. Setiap proses pembuatan kebijakan ini tidak lepas dari peraturan-peraturan yang harus dipedomani dalam penyusunannya. Hal ini karena hukum yang ada telah mengatur prinsip-prinsip yang menjadi urusan publik. Oleh karena itu dalam membuat kebijakan publik, dasar-dasar hukum ini harus dipedomani dan diikuti.

Faktor kedua adalah interest atas keuntungan yang diperoleh atas relasi antar aktor yang terlibat dalam pembuatan kebijakan. Kemiskinan merupakan stigma sekaligus isu yang seksi untuk dijual di Gunungkidul, sehingga banyak pihak, terutama LSM yang "menjual" kemiskinan sebagai proyek untuk mendapatkan pendanaan dari sponsor atau donor. Kemiskinan ini kemudian menjadi masalah bersama sekaligus potensi proyek bersama. Pemerintah Gunungkidul tidak memiliki banyak dana untuk menyusun kebijakan penanggulangan kemiskinan daerah, sedangkan LSM memiliki dana untuk riset dan proyek penanggulangan kemiskinan, sehingga terjadi kerjasama untuk melakukan kegiatan bersama, termasuk kegiatan perumusan kebijakan penanggulangan kemiskinan daerah. Dalam penyusunan kebijakan penanggulangan kemiskinan daerah di Kabupaten Gunungkidul ini, dana yang dimiliki oleh pemerintah daerah hanya cukup digunakan untuk dua kali kegiatan Workshop, sehingga dua Workshop yang lain disandingkan dengan pendanaan dari IRE.

Faktor ketiga adalah pengalaman dari pemerintah daerah. Pemerintah daerah, dalam hal ini Bappeda selaku koordinator perumus kebijakan dalam sehari-hari banyak berinteraksi dengan banyak pihak, termasuk LSM. Interaksi ini banyak memberikan tambahan pengetahuan dan inspirasi. Dalam riset dengan IRE, pemerintah juga terlibat langsung, sehingga dalam memasukkan pembelajaran dari riset IRE ke dalam kebijakan penanggulangan kemiskinan daerah, pemerintah kabupaten Gunungkidul tidak ragu lagi karena mereka ikut mengalaminya dan memiliki gambaran riil terkait daerahnya. Dengan demikian pengalaman ini sangat membantu untuk adopsi pembelajaran ke dalam kebijakan.

Dari bukti-bukti yang ada, bahwa pembelajaran yang dilakukan oleh pemerintah Gunungkidul adalah conceptual learning yang mengubah cara pandang tentang penanggulangan kemiskinan. Bentuk policy learning yang terjadi adalah dengan imitasi selektif. Imitasi yang dilakukan hanya selektif dengan menggunakan suatu pembelajaran yang perlu saja. Pembuatan kebjijakan tidak menunjukkan detail program yang dijadikan rujukan dan bagaimana program itu bekerja, tetapi mereka hanya mengambil sebagian kecil dari 
program dan mengklaim telah mengadopsinya dalam sebuah program yang didesain independen dari program sumber.

Adopsi ke dalam kebijakan dengan imitasi selektif ini hanya dijadikan sebagai anekdot daripada pembuktian, sebagai tanda legitimasi daripada pembelajaran sebagai kekuatan motivasi. Dalam reformulasi kebijakan penanggulangan kemiskinan daerah, karena kebijakan yang ada hanya sekedar di dokumen, implementasinya tidak dijalankan dengan disiplin. Dalam rencana pembangunan Kabupaten Gunungkidul, konsep baru penanggulangan kemiskinan ini dicoba untuk dikawal untuk bisa dilakukan pada tahun 2014 di tiga desa yaitu Desa Kerpus, Desa Mertelu, Desa Kembangsuco berupa pendataan potensi.

Dengan demikian, menjadi jelas bahwa motif untuk melakukan policy learning adalah adanya mandat regulasi dari pusat untuk membuat kebijakan publik dan peluang kerjasama mutualisme yang ditawarkan dari non-government organization untuk pembiayaan penyusunan kebijakan publik. Problematisasi masalah dalam policy learning reformulasi kebijakan publik penanggulangan kemiskinan daerah bukan terletak pada efektivitas dan evaluasi kebijakan sebelumnya, namun lebih ke peluang dukungan fiskal kepada pemerintah daerah dengan tetap memenuhi kewajiban dari pemerintah pusat dan tidak menimbulkan kegiatan baru yang berpotensi membebani fiskal.

Aktor pertama yang berpengaruh adalah pemerintah pusat. Pengaruh pemerintah pusat diwujudkan dalam regulasi-regulasi yang sifatnya memaksa, sehingga pemerintah daerah harus mengikutinya. Kebijakan penanggulangan kemiskinan daerah yang disusun merupakan amanah dari peraturan perundangundangan, yaitu Peraturan Presiden Nomor 15 Tahun 2010. Sehingga pembuatan dokumen strategi kebijakan penanggulangan kemiskinan daerah wajib dilakukan karena merupakan perintah peraturan perundang-undangan. Sehingga strategi nasional yang ada wajib dipedomani dan dijadikan acuan. Dengan demikian, pemerintah daerah mau tidak mau harus meng-copy strategi nasional penanggulangan kemiskinan.

Aktor yang berpengaruh berikutnya adalah non-government organization (NGO). NGO melalui program dan hasil risetnya berperan dalam mempengaruhi isi kebijakan penanggulangan kemiskinan daerah. Kemiskinan merupakan stigma sekaligus isu yang seksi untuk dijual, sehingga kemiskinan di Gunungkidul bisa dikomodifikasi sebagai proyek untuk mendapatkan pendanaan dari sponsor atau donor. Pemerintah Gunungkidul tidak memiliki banyak dana untuk menyusun kebijakan penanggulangan kemiskinan daerah, sedangkan NGO memiliki dana untuk riset dan proyek penanggulangan kemiskinan. Sehingga terjadi kerjasama antara pemerintah dan NGO untuk melakukan kegiatan bersama, termasuk kegiatan perumusan kebijakan penanggulangan kemiskinan daerah. Aktor berikutnya adalah birokrasi pemerintah. Birokrasi sebagaimana dipandang dalam riset ini adalah aktor plural yang memiliki banyak kepentingan di dalamnya.

\section{Hasil Reformulasi Kebijakan Penanggulangan Kemiskinan Daerah}

Paradigma yang dipakai dalam SPKD 2012-2015 adalah penangangan kemiskinan dimulai dari pemberdayaan manusia sebagai dasar pemberdayaan 
masyarakat. Ini membuktikan bahwa pelibatan masyarakat (khususnya masyarakat miskin) sangat diperlukan dalam perencanaan, pelaksanaan, dan pemanfaatan kegiatan-kegiatan penanggulangan kemiskinan. Oleh karena itu, keberdayaan kelembagaan masyarakat benar-benar dibutuhkan dalam rangka membangun organisasi masyarakat yang menjadi wadah perjuangan warga miskin. Wadah ini penting untuk menyuarakan aspirasi serta kebutuhan mereka, sehingga mampu mempengaruhi proses pengambilan keputusan berkaitan dengan kebijakan publik di tingkat lokal.

Artinya, pendekatan yang digunakan adalah pendekatan community driven development dalam penanggulangan kemiskinan daerah. Penanggulangan kemiskinan dengan model ini diharapkan memberikan kontribusi penanggulangan kemiskinan yang bersifat multi dimensional dan struktural. Khususnya yang terkait dengan dimensi-dimensi politik, sosial, dan ekonomi. Sehingga dalam jangka panjang mampu menyediakan aset yang lebih baik bagi warga masyarakat miskin. Baik berkaitan dengan peningkatan pendapatan, kualitas perumahan dan pemukiman, maupun terkait dengan aspirasi mereka dalam proses pengambilan keputusan.

Kebijakan penanggulangan kemiskinan daerah di Kabupaten Gunungkidul yang baru juga menganggap bahwa penanggulangan kemiskinan harus menjadi sebuah "gerakan bersama". Penanggulangan kemiskinan tidak hanya dilakukan oleh pemerintah pusat dan daerah saja, namun juga harus melibatkan dunia usaha, organisasi non-pemerintah dan komponen masyarakat lainnya. Hal ini berarti bahwa pemerintah daerah menganggap bahwa kemiskinan bukan hanya semata tanggung jawab pemerintah. Kalau ada kemiskinan itu bukan karena salah pemerintah semata, namun merupakan tanggung jawab bersama dan harus ditangani bersama.

Dalam SPKD 2012-2015 juga diungkapkan bahwa kegiatan penanggulangan kemiskinan di Kabupaten Gunungkidul harus berjalan selaras dengan kebutuhan dan potensi daerah. Kebijakan penanggulangan kemiskinan bertumpu pada kebijakan publik yang berpihak pada orang miskin (pro poor policy), yang diterjemahkan dalam pembangunan yang bepihak pada orang miskin (pro poor development) dan pertumbuhan ekonomi yang berpihak pada orang miskin (pro poor growth). Hal ini berarti bahwa penanggulangan kemiskinan menggunakan cara pandang berbasis potensi yang ada di daerah tersebut. Dengan demikian, kebijakan yang diambil tidak hanya berdasarkan masalah semata (problem based), namun juga menggunakan potensi daerah yang bersangkutan (asset based).

Untuk melihat lebih detail strategi dan kebijakan yang baru hasil policy learning yang dirumuskan dalam SPKD 2012-2015 berikut diuraikan kebijakan makro strategis, makro operasional (program utama), kebijakan mikro strategis (program) dan mikro operasional (kegiatan). Kebijakan makro strategisnya terdiri dari lima strategi, yaitu; memperbaiki dan mengembangkan sistem perlindungan sosial bagi penduduk, meningkatkan akses terhadap pelayanan dasar, memberdayakan penduduk miskin, pembangunan inklusif, dan kebijakan inovasi daerah. Keempat strategi awal merupakan strategi yang wajib dicantumkan, karena merupakan strategi pemerintah pusat. Strategi ini sama persis dengan yang 
tertuang dalam dokumen Strategi Nasional Penanggulangan Kemiskinan. Sehingga strategi nomor satu sampai empat, merupakan hasil fotocopy. Sedangkan strategi kebijakan inovasi daerah merupakan imitasi selektif dari hasil penelitian bersama antara IRE dan pemerintah kabupaten Gunungkidul.

Sistem perlindungan sosial dimaksudkan untuk membantu individu dan masyarakat menghadapi goncangan-goncangan dalam hidup, seperti jatuh sakit, kematian anggota keluarga, kehilangan pekerjaan, ditimpa bencana atau bencana alam, dan sebagainya. Sistem perlindungan sosial yang efektif akan mengantisipasi agar seseorang atau masyarakat yang mengalami goncangan tidak sampai jatuh miskin. Sedangkan perbaikan akses terhadap pelayanan dasar berkaitan akses terhadap pelayanan pendidikan, kesehatan, air bersih, sanitasi, pangan, dan gizi. Perbaikan akses ini akan membantu mengurangi biaya yang harus dikeluarkan oleh kelompok masyarakat miskin.

Upaya memberdayakan penduduk miskin menjadi sangat penting untuk meningkatkan efektivitas dan keberlanjutan penanggulangan kemiskinan. Dalam upaya penanggulangan kemiskinan sangat penting untuk tidak memperlakukan penduduk miskin semata-mata sebagai obyek pembangunan. Upaya untuk memberdayakan penduduk miskin perlu dilakukan agar penduduk miskin dapat berupaya keluar dari kemiskinan dan tidak jatuh kembali ke dalam kemiskinan. Pembangunan yang inklusif diartikan sebagai pembangunan yang mengikutsertakan dan sekaligus memberi manfaat kepada seluruh masyarakat. Partisipasi menjadi kata kunci dari seluruh pelaksanaan pembangunan.

Selain wajib mengacu pada empat strategi nasional tersebut, pemerintah daerah juga merumuskan kebijakan dan strategi penanggulangan kemiskinan sesuai situasi dan kemampuan daerah. Dengan meihat potensi yang ada, strategi penanggulangan kemiskinan di Gunungkidul sebagai pijakan program tahun 20122015 meliputi lima strategi: unifikasi data dan validasi data sasaran penanggulangan kemiskinan; meningkatkan kemitraan dengan pihak swasta, dunia usaha, perguruan tinggi dan lembaga sekolah; pengembangan industrialisasi pedesaan (seperti desa wisata, sentra industri kerajinan, sentra industri olahan pangan, dan sejenisnya); memperkuat institusi lokal menjadi energi positif dalam penanggulangan kemiskinan; dan penguatan kelembagaan penanggulangan kemiskinan.

Strategi-strategi tersebut tertuang dalam dokumen SPKD 2012-2015. Dokumen tersebut secara normatif merupakan arah pandu gerakan penanggulangan kemiskinan daerah. Aksi penanggulangan kemiskinan daerah diwujudkan dalam bentuk program dan kegiatan pembangunan. Namun sayangnya program dan kegiatan pembangunan yang mengacu pada dokumen ini tidak bisa memunculkan program baru yang benar-benar dirancang untuk mengimplementasikan SPKD 2012-2015 secara khusus. Konsep-konsep dalam SPKD 2012-2015 diterapkan dalam program yang sudah ada sebelumnya di berbagai SKPD yang terkait.

Sebagai contoh, program pendataan potensi daerah yang merupakan kegiatan tahunan Bappeda biasanya program itu berisi pendataan update data informasi perkembangan pembangunan kabupaten. Namun, mulai tahun 2013 sudah 
diusulkan untuk rencana di tahun 2014, untuk diisi strategi industrialisasi desa dengan terlebih dahulu melakukan pengkajian pengembangan potensi di tiga desa percobaan konsep SPKD yaitu Desa Kerpus, Desa Kembangsuco dan Desa Mertelu. Konsep ini rencananya akan dimasukkan ke dalam RKPD tahun 2014. Sedangkan implementasi rencana konsep industrialisasi desa secara keseluruhan di ketiga desa tersebut baru akan dicoba di tahun 2015.

Implementasi strategi tentang unifikasi data juga baru bisa dianggarkan di tahun 2014. Sehingga dengan demikian diharapkan Kabupaten Gunungkidul akan memiliki data tandingan dari BPS yang dianggap tidak objektif dalam mengukur angka kemiskinan. Sedangkan implementasi strategi sinergi dengan pihak ketiga baru berproses pada tahun 2013. Strategi ini tidak membutuhkan anggaran khusus karena strategi ini dilakukan dengan melakukan kerjasama kegiatan-kegiatan penanggulangan kemiskinan yang akan masuk ke Gunungkidul, baik dari sekolah, universitas maupun swasta.

Implementasi SPKD 2012-2015 ini sangat terlambat karena SPKD yang harusnya mulai dipedomani sejak tahun 2012 sampai 2015 ternyata baru dicetak tahun 2013 awal dan baru bisa dipakai untuk pedoman pada saat tahun 2013 untuk penyusunan Angaran 2014. Hal ini pastinya menjadi sangat sulit untuk benar-benar mengimplementasikan konsep SPKD seperti yang diidealkan.

\section{Kesimpulan}

Policy learning dalam reformulasi kebijakan penanggulangan kemiskinan daerah terjadi karena adanya interest pemerintah daerah. Interest tersebut berkaitan dengan tawaran kemitraan dari pihak lain (IRE) karena lemahnya kapasitas fiskal daerah, keterbatasan waktu, dan sumber daya manusia. Hal tersebut mendorong pemerintah untuk melakukan conceptual learning dan menerapkan imitasi selektif. Conceptual learning terlihat dari adanya perubahan cara pandang terhadap penanggulangan kemiskinan daerah, dari berbasis masalah (problem based) ke penanggulangan kemiskinan berbasis aset (asset based). Sedangkan imitasi selektif terwujud dengan mengambil elemen tertentu untuk dimasukkan ke dalam kebijakan dan tidak mengambil secara detail karena menghindari resiko politik. Policy learning model ini kemudian berimplikasi terhadap implementasi kebijakan yang tidak tegas membuat kegiatan baru, namun mendompleng dalam program dan kegiatan yang sudah ada.

Dengan demikian, stimulus pembelajaran ini bukanlah merupakan "ketidakpuasan" seperti yang diteorikan oleh Richard Rose (1991), namun merupakan interest yang dimanfaatkan oleh pemerintah sebagai momentum reformulasi kebijakan penanggulangan kemiskinan daerah. Pendek kata, temuan dalam penelitian ini menunjukkan bahwa yang menstimulasi melakukan perubahan kebijakan baru bukanlah ketidakpuasan dari internal pembuat kebijakan. Namun, yang menstimulasi terjadinya policy learning adalah faktor eksternal, yaitu peluang keuntungan yang dimiliki pemerintah dalam simbiosis mutualisme dengan pihak ketiga. Policy learning ini adalah proses politik yang 
melibatkan interaksi banyak aktor, mulai dari pemerintah pusat, non- government organization, serta pihak birokrasi yang plural dengan kepentingan yang beragam.

Dari dokumen kebijakan penanggulangan kemiskinan daerah di Gunungkidul (2012-2015), policy learning memang terjadi, namun ketika melihat implementasi kebijakan ini ke dalam program dan kegiatan, kebijakan ini tidak menimbulkan program dan kegiatan baru sebagai instrumen kebijakan. Implementasi program inipun tidak bisa sesegera mungkin, rencana baru diawali pada tahun 2014 dan akan dilakukan di tahun 2015. Implementasi dilakukan di tiga lokasi desa sebagai perwujudan bahwa kebijakan ini benar-benar serius akan dilakukan di tengah kekhawatiran resistensi dari pihak lain. Dengan demikian, pemerintah daerah melakukan imitasi selektif yang menghindari pengambilan elemen-elemen penting program karena dikhawatirkan menimbulkan biaya politik yang besar.[]

\section{Acknowledgements}

Artikel ini diadaptasi dari Tesis saya yang diajukan untuk gelar magister bidang Politik dan Pemerintahan, Fakultas Ilmu Sosial dan Ilmu Politik, Universitas Gadjah Mada, Indonesia, 2013.

\section{Daftar Pustaka}

Bappeda Pemkab Gunungkidul. 2007. Strategi Penanggulangan Kemiskinan Daerah Gunungkidul 2007-2011. Pemkab Gunungkidul.

Bappeda Pemkab Gunungkidul. 2012. Strategi Penanggulangan Kemiskinan Daerah Gunungkidul 2012-2015. Pemkab Gunungkidul.

Bennet, Collin J dan Michael Howlett. 1992. "The lesson of learning: Reconcilling theories of policy learning and policy change." Policy science 25: 275-294.

Dolowitz, David P., and David Marsh. 2000. "Learning from abroad: The role of policy transfer in contemporary policy-making." Governance: An International Journal of Policy and Administration 13, no. 1: 5-24.

Hall, Peter A. 1993. "Policy Paradigms, Social Learning and The State: The Case of Economic Policy Making in Britain." Comparative Politics 25, no. 3 (April): 275296.

Institute for Research and Empowerment. 2011. Mempertemukan Dua Hulu: Pelajaran Desentralisasi Fiskal dan Penanggulangan Kemiskinan dari Gunungkidul. IRE dan Tifa Foundation.

Jatmika, Irawan, Hasrul Hanif dan Wasingatu Zakiyah. 2010. Optimalisasi Upaya Penanggulangan Kemiskinan Responsif Gender di Kabupaten Gunungkidul Melalui Pengembangan Inovasi Perencanaan dan Penganggaran Daerah: Sebuah Evaluasi Kebijakan. IDEA-Pemkab Gunungkidul. 
Kemp, Rene dan Rifka Weehuizen. 2005. Policy learning, what does it mean and how can we study it. Oslo: NIFU STEP.

May, Peter J. 1992. "Policy Learning and Failure." Journal Public Policy 12, no. 4: 331-354.

Ma'arif Institute. 2007. Studi Awal Kemiskinan di Gunungkidul. Jakarta: Ma'arif Institute.

Peraturan Presiden Republik Indonesia Nomor 15 Tahun 2010 tentang Percepatan Penanggulangan Kemiskinan.

Rose, Richard. 2005. Learning from comparative public policy, a practical guide. Routledge, simultaneously published in USA and Canada.

Rose, Richard. 1991. "What is lesson-drawing?." Journal of Public Policy 11, no. 1:330.

Suharto. 2007. Kebijakan Sosial sebagai Kebijakan Publik. Alvabeta.

Sulistiyani, Ambar Teguh. 2004. Kemitraan dan model-model pemberdayaan. Gava Media. Yogyakarta.

UNHABITAT. 2008. Asset Based Approach To Community Development. United Nation Human Settlement Programe. Nairobi.

Winnick, Louis. 1966. "Place Prosperity vs. People Prosperity: Welfare considerations in the geographic redistributions of economic activity." In Essays in Urban Land Economics: In Honor of the Sixty Fifth Birthday of Leo Grebler Edited by. Los Angeles: University of California.

\section{Biografi Penulis}

Fajar Sodiq Irawan adalah Kepala Seksi Pelatihan Keuangan dan Aset Desa (Widyaiswara Ahli Muda) Balai Pemerintahan Desa Yogyakarta, Kementerian Dalam Negeri Indonesia. Ia menyelesaikan program Magister di Departemen Politik dan Pemerintahan, Universitas Gadjah Mada, Indonesia. Ia memiliki wawasan yang mendalam berkaitan dengan topik desentralisasi dan politik pemerintahan desa yang memang menjadi minat kajiannya selama ini.

Email: fajarbaru@gmail.com 